\title{
PENTINGNYA KONSEP 3 IN 1 IN THE LAND ACQUTITION PADA PROSES PENYERAHAN TANAH FASILITAS UMUM (FASUM).
}

\author{
Husni Hafit; Dosen Pembimbing Dr. Jarot Muliawan, S.H., C.N., M.Kn. \\ Magister Kenotariatan, Fakultas Hukum Universitas Narotama Surabaya \\ Husnilucky07@gmail.com
}

\begin{abstract}
ABSTRAC
Land is essential for human life. On land, humans also build houses as shelter and build various other buildings for offices and so on. Land also contains various kinds of natural resources that can be utilized by humans. The implementation of house construction as a shelter is inseparable from housing development, where the house is a basic human need which has the main function as a place to live or settle, apart from that housing also functions as a place for community interaction which is always done as a useful habit. for the welfare, security and happiness of life as a social being, housing development is certainly inseparable from the previous stages as stated in the 3 In 1 The Land Aquitition Concept
\end{abstract}

\section{ABSTRAK}

Tanah merupakan hal penting bagi kehidupan manusia. Diatas tanah pula manusia membangun rumah sebagai tempat bernaung dan membangun berbagai bangunan lainnya untuk perkantoran dan sebagainya. Tanah juga mengandung berbagai macam kekayaan alam yang dapat dimanfaatkan manusia. Pelaksanaan pembangunan rumah sebagai tempat bernaung itu tidak lepas dari pembangunan perumahan, dimana rumah merupakan kebutuhan dasar (basic needs) manusia yang berfungsi utama sebagai tempat tinggal atau menetap, terlepas dari itu perumahan juga berfungsi sebagai tempat berinteraksi masyarakat yang selalu dilakukan sebagai suatu kebiasaan yang berguna untuk kesejahteraan, keamanan dan kebahagiaan hidup sebagai mahluk sosial, pembangunan kawasan hunian rumah tinggal maupun tempat usaha tentu tidak lepas dari tahapan - tahapan yang di lalui sebelumnya seperti halnya yang tertuang dalam Konsep 3 In 1 The land Aquitition. 


\section{LATAR BELAKANG}

Tiada Harta kekayaan yang lebih berfungsi dari tanah yang dimiliki manusia. Karena tidak ada kegiatan manusia yang dapat terlaksana dan terlepas sama sekali dari tanah. Tanah dalam wilayah Negara Kesatuan Republik Indonesia adalah salah satu sumber daya alam yang paling utama, yang bisa memiliki nilai fundamental paling dalam bagi rakyat Indonesia. Tanah juga memiliki fungsi yang sangat strategis dalam memenuhi kebutuhan Negara serta rakyat Indonesia yang populasinya semakin beragam dan meningkat, baik pada tingkat nasional maupun dalam hubungan dengan dunia internasional. Menurut Kamus Hukum pengertian Tanah adalah " permukaan Bumi ataupun susunan lapisan bumi yang diatas sekali, keadaan bumi disuatu tempat, permukaan bumi yang diberikan batasan dan daratan". Tanah ialah bagian dari bumi yang disebut permukaan Bumi.

Dalam Undang-Undang Dasar Negara Republik Indonesia Tahun 1945 menyatakan secara tegas bahwa negara Republik Indonesia adalah negara hukum.. Hukum yang baik, sebagaimana mengutip pendapat Max Weber, seharusnya dapat menciptakan birokrasi yang baik, dan birokrasi yang baik akan menumbuhkan investasi yang baik pula. Artinya, kebijakan, kelembagaan, serta prosedur pertahanan yang baik, juga akan menimbulkan serta mendatangkan kemakmuran dan kesejahteraan kepada masyarakat, dan sebaliknya, hukum dan kebijakan yang burukakan menciptakan birokrasi yang buruk pula, serta menimbulkan ketidakadilan ditengah masyarakat. Untuk itu pengaturan mengenai pengelolaan dan penyerahan prasarana, sarana dan Uilitas yang biasa disebut dengan PSU untuk suatu kawasan perumahan dan pemukiman harus mencerminkan tujuan hukum itu sendiri yaitu keadilan, kemanfaatan dan kepastian hukum. Jika hal tersebut terpenuhi maka akan tercipta masyarakat yang makmur dan sejahtera sebagaimana amanat pasal 33 ayat (3) Undang - Undang Dasar Negara Republik Indonesia tahun 1945.

Tanah dalam daerah Republik Indonesia ialah salah satu sumber energi alam 
utama, yang tidak hanya memiliki nilai batiniah yang mendalam untuk rakyat Indonesia, juga berperan sangat strategis dalam penuhi kebutuhan negara serta rakyat Indonesia yang kian bermacam- macam serta bertambah, baik pada tingkatan nasional ataupun dalam hubungannya dengan dunia Internasional. Tiada harta kekayaan yang lebih berfungsi dari tanah yang dimiliki manusia. Karena tidak ada kegiatan manusia yang dapat terlaksana terlepas sama sekali dari tanah. Tanah memiliki fungsi :

a) Tanah di kota yang dipergunakan sebagai wadah adalah meliputi hak-hak primer atas tanah yang terdiri dari : Hak Milik (untuk perumahan dan usaha), Hak Guna Bangunan (untuk kantor, tempat usaha, pabrik atau industri), Hak Pakai, Hak Pengelolaan (khusus untuk instansi pemerintah) dan tanah dengan Hak sekunder yang terdiri dari : Hak Sewa, Hak Pakai dan Hak Guna Bangunan.

b) Sedangkan tanah sebagai faktor produksi yang berada di desa adalah meliputi tanah dengan Hak primer yang terdiri dari Hak Milik (untuk sawah dan kebun), Hak Guna Usaha (untuk perkebunan, peternakan, dan perikanan), Hak Pakai, dan tanah dengan hak sekunder yang terdiri dari Hak Sewa, Hak Pakai, Hak Usaha Bagi Hasil, Hak Gadai, Hak menumpang .

Tanah sebagai Fungsi sosial karena berfungsi sebagai keseimbangan, keadilan, kemanfaatan dan bercorak kebenaran. Sehingga hendak menampilkan guna individu dalam bingkai kemasyarakatan yang membagikan bermacam ikatan keselarasan yang harmonis serta saling penuhi guna meminimalisir kompleksitasnya bermacam kasus yang bisa jadi serta hendak timbul dalam kehidupan sosial kemasyarakatan, bangsa serta negera. Sehingga diperlukan kesadaran dalam diri rakyat Indonesia bersama - sama pemerintah untuk saling perduli dan menjaga kelestarian tanah sertalingkungan sekitarnya. Dijelaskan dalam bab ke 8 (delapan) pasal 723 KUHPerdata, bahwa "pemilik tanah tak berwajib memperbaiki sesuatu kerusakan. Sebaiknya pun pengusahalah berwajib memelihara tanah dalam usahanya dan melakukan perbaikan akan 
segala kerusakan biasa. Ia boleh memperbaiki tanah itu dengan mendirikan gedung-gedung di atasnya, dengan membukanya atau menanaminya.

Tanah sebagai objek yang dapat dimiliki dan dimanfaatkan sesuai kebutuhan sering memicu konflik, dan seiring perkembangan waktu telah bertumbuh sebagai benda ekonomi yang sangat penting, yaitu sebagai objek perniagaan dan objek spekulasi. Di satu sisi, tanah juga harus dipergunakan dan dimanfaatkan untuk sebesar-besarnya kesejahteraan rakyat lahir batin, adil dan merata, sementara di lain pihak harus dijaga kelestariannya. Untuk Melaksanakan Prinsip - prinsip dasar tersebut dalam hubungannya dengan tanah, ditetapkan hukum agrarian Nasional yang tertuang dalam Undang Undang Nomor 5 tahun 1960 tentang Peraturan dasar pokok Agraria atau disebut UUPA yang mengatur prinsip dasar mengenai hak kepemilikan dan pemanfaatan tanah di Indonesia.

Fungsi sosial atas tanah juga memungkinkan hak milik atas tanah menjadi hapus apabila kepentingan umum menghendakinya, sebagaimana ketentuan Pasal 18 UUPA. Sehingga apabila kepentingan umum menghendaki diambilnya hak atas tanah, maka pemegang hak harus melepaskannya atau menyerahkan hak atas tanah dengan memperoleh ganti rugi melalui mekanisme pencabutan hak atas tanah. Selanjutnya, dengan fungsi sosial hak atas tanah, pemegang hak atas tanah tidak boleh menelantarkannya karena dapat mengakibatkan hapusnya atau batalnya hak yang bersangkutan sebagaimana Penjelasan Pasal 27 UUPA. Oleh karena penggunaan lahan berarti penggunaan ruang, maka untuk menciptakan kelestarian alam diperlukan perencaan tata ruang. Dan dalam hal ini masyarakat sebagai pengguna tata ruang dan tata penggunaan tanah mempunyai hak dan kewajiban. Dalam penataan ruang, setiap orang berhak untuk:

a) Mengetahui perencanaan tata ruang.

b) Menikmati sebab bertambahnya manfaat nilai ruang sebagai akibat penataan ruang. 
c) Memperoleh penggantian yang layak atas kerugian yang timbul akibat pelaksanaan kegiatan pembangunan yang tidak sesuai dengan rencana tata ruang.

d) Mengajukan keberatan kepada pejabat yang berwenang terhadap pembangunan yang tidak sesuai dengan perencanaan tata ruang di wilayahnya.

e) Mengajukan tuntutan pembatalan izin dan penghentian pembangunan yang tidak sesuai dengan perencanaan tata ruang kepada pejabat berwenang.

f) Mengajukan gugatan ganti kerugian kepada pemerintah dan/atau pemegang izin apabila kegiatan pembangunan yang tidak sesuai dengan rencana tata ruang menimbulkan kerugian.

Sedangkan dalam pemanfaatan ruang, setiap orang berkewajiban:

a) Mematuhi perencana tata ruang yang telah ditetapkan;

b) Memanfaatkan ruang sesuai izin pemanfaatan ruang dari pejabat yang berwenang;

c) Mematuhi ketentuan yang ditetapkan dalam persyaratan izin pemanfaatan ruang;

d) Memberikan akses terhadap kawasan yang oleh ketentuan peraturan perundang-undangan dinyatakan sebagai milik umum. ${ }^{1}$

Suatu kawasan bangunan baik rumah tinggal maupun tempat usaha adalah tempat awal beaktifitas dan bersosialisasi antara masyarakat. Sarana suatu kawasan hunian rumah tinggal dan non rumah tingal tidak terlepas dari kelengkapan Ruang sarana umum, seperti halnya Fasilitas Umum (Fasum) yang memadai untuk menunjang kehidupan sosial dan ekonomi masyarakat, menciptakan rasa nyaman, aman, sebagai hunian tempat tinggal maupun tempat usaha. Pembangunan kawasan perumahan atau tempat usaha idealnya juga harus dibangun Ruang Fasilitas Umum oleh pihak developernya, melihat

${ }^{1}$ http://bisnisproperty.net/dokumen-properti-yang-terkait-tata-ruang, diakses hari Sabtu tanggal 20 Desember $2014: 22.24$ WIB. 
pentingnya Fasilitas Umum yang harus ada seperti tempat peribadahan, RTH ( Ruang Terbuka hijau ), pertamanan, TPS ( tempat pembuangan sampah dan lain sebagianya sesuai yang telah diterangkan dalam pasal 7,8 dan 9 Peraturan Menteri Dalam Negeri ang biasa disingkat Permendagri nomor 9 tahun 2009, dan dalam pembangunannya hendaknya mendapatkan perhatian lebih dari pihak developer itu sendiri. Dijelaskan bahwa dalam Pasal 7, 8, dan 9 permendagri No. 9 Tahun 2009 yang mengatur Tentang Pedoman Penyerahan Prasarana, sarana, dan Utilitas ( PSU ) Perumahan dan Permukiman Daerah, sarana dan utilitas perumahan yang harus dimiliki sebuah perumahan atau tempat usaha, dengan jelas bahwasannya Negara melalui pemerintah sangat berperan dalam mendukung kegiatan sosial ekonomi dan budaya dari masyarakat.

Dengan demikian maka jelas bahwa dalam pembangunan perumahan atau tempat usaha seyogyanya harus ada sarana umum, namun kenyatan yang ada bahwa pembangunan Fasilitas Umum di daerah perumahan dan tempat usaha sering kali disepelekan oleh pihak pengembangnya, yang dimana Fasilitas Umum tidak dibangun bahkan disalah gunakan peruntukkannya untuk diperjual belikan karena adanya keinginan dari pihak-pihak tertentu hanya untuk memperoleh keuntungan semata tanpa memperhatikan peraturan yang ada, sehingga banyak tanah fasum yang beralih fungsinya, bahkan ada yang dengan sengaja untuk tidak menyerahkan kepada pemerintah daerah, hingga dapat menimbulkan permasalahan hukum serta banyak menimbulkan masalah sosial lainnya dan berdampak negative padalingkungan sekitarrnya.

\section{Rumusan Masalah}

Berdasarkan latar belakang yang telah diuraikan diatas, maka dapat ditarik dua permasalahan yang perlu dikemukakan. Adapun perumusan masalah yang akan dibahas dalam penelitian ini, yaitu:

1. Apa bentuk penerapan konsep 3 in 1 in the lan acqutition dalam proses 
pengadaan dan penyerahan fasum kawasan prumahan dan pemukiman kepada pemerintah daerah?

2. Apa status tanah fasum yang disalah gunakan peruntukkannya dan diperjual belikan?

\section{METODE PENELITIAN.}

Metode yang digunakan dalam penelitian ini adalah metode penelitian yuridis normatif yang menekankan pada norma-norma hukum dengan menganalisa peraturan perundang-undangan yang berlaku. Dalam Penelitian ini peneliti menggunakan dua metode pendekatan masalah, yaitu : a) Statute Approach, yaitu pendekatan dengan menelaah semua Peraturan Perundang-Undangan yang bersangkut paut dengan permasalahan (isu hukum) yang sedang dihadapi; dan b) Conseptual Approach, yaitu pendekatan yang beranjak dari pandanganpandangan dan doktrin-doktrin yang berkembang di dalam ilmu hukum.

\section{PEMBAHASAN.}

\section{Bentuk penerapan konsep 3 in 1 in the lan acqutition dalam proses pengadaan dan penyerahan PSU kawasan prumahan dan pemukiman kepada pemerintah daerah.}

Penggunaan tanah pada prinsipnya harus sesuai dengan perencanaan tata ruang pemerintah daerah setempat yang disebut Rencana Tata Ruang Wilayah (RTRW) yang bertujuan untuk menghindari penggunaan tanah yang tidak sesuai dengan peruntukkan. Dalam pemanfaatan ruang, setiap orang wajib memiliki izin pemanfaatan ruang dan wajib melaksanakan setiap ketentuan perizinan dalam pelaksanaan pemanfaatan ruang. Izin pemanfaatan ruang diberikan kepada calon pengguna ruang yang akan melakukan kegiatan pemanfaatan ruang pada suatu kawasan/zona tertentu berdasarkan Rencana 
Tata Ruang Wilayah (RTRW) pemerintah daerah setempat. Pemberian Izin Pemanfaatan Ruang disertai persyaratan teknis dan persyaratan administratif sesuai ketentuan peraturan perundang-undangan yang berlaku. Ketentuan peraturan perundang-undangan yang dimaksud adalah ketentuan tentang perizinan yang diterbitkan oleh masing-masing sektor dan/atau lnstansi yang berwenang, misalnya ketentuan Izin Lokasi ( Siteplan) dan IMB ( Izin Mendirikan Bangunan ) untuk kegiatan pembangunan kawasan rumah tinggal dan non rumah tinggal. Pembangunan perumahan tentu tidak lepas dari tahapan - tahapan yang di lalui sebelumnya seperti halnya yang tertuang dalam Konsep 3 In One in The land Aquitition sebagaiamana disebutkan Undang-undang Pokok Agararia yang biasa disebut UUPA dalam Pasal 11 ayat (1) menegaskan bahwa Pemberian Hak Atas Tanah sebagaimana dimaksud dalam Pasal 9 dilakukan sesuai dengan ketentuan peraturan perundangundangan yang berlaku. Untuk memahami secara komprehensif tentang Sertifikasi dengan Hak Atas Tanah berupa Hak Pengelolaan diperlukan konsep 3 in 1 in the Land Acquisition ${ }^{2}$ yang membagi tahapan perolehan Hak Pengelolaan atas tanah guna untuk pembangunan baik pembangunan untuk kawasan hunian rumah tinggal maupun kawasan non rumah tinggal oleh seorang developer tidak bisa lepas dari 3 ( tiga ) titik proses tahapan yang harus dilaluinya, yaitu ;

\section{Titik Start ( Perijinan Tanah)}

Perizinan tanah merupakan titik start kegiatan pendaftaran tanah dengan status Hak Pengelolaan. Perizinan yang dimaksud yaitu mengenai:

Subjek/pemohon Hak Pengelolaan;

Berdasarkan Pasal 67 Peraturan Meteri Negara Agraria/Kepala Badan Pertanahan Nasional Nomor 9 Tahun 1999, subjek/pemohon Hak Pengelolaan yaitu:

a. Instansi Pemerintah termasuk Pemerintah Daerah;

\footnotetext{
${ }^{2}$ Strategi Ampuh Kuasai Hukum Pertanahan Dr. H. Jarot Muliawan, S.H., C.N., M.kn.
} 

b. Badan Usaha Milik Negara;
c. Badan Usaha Milik Daerah;
d. PT. Persero;
e. Badan Otoritas;
f. Badan-badan hukum Pemerintah lainnya yang ditunjuk pemerintah.

Keterangan mengenai pemohon yaitu terdiri dari: Nama badan hukum, tempat kedudukan, akta atau peraturan pendiriannya sesuai dengan ketentuan peraturan perundang-undangan yang berlaku.

1. Rencana penggunaan tanah.

2. Jenis tanah : pertanian atau non pertanian

Kelengkapan berkas yang harus disiapkan yaitu:

1. Foto copy identitas permohonan atau surat keputusan pembentukannya atau akta pendirian perusahaan sesuai dengan peraturan perundang-undangan yang berlaku;

2. Rencana pengusahaan tanah jangka pendek dan jangka panjang;

3. Izin lokasi atau surat izin penunjukan penggunaan tanah atau surat izin pencadangantanah sesuai dengan Rencana tata ruang Wilayah.

\section{Titik Decision ( Penguasaan tanah )}

Penguasaan tanah merupakan titik decision yaitu kegiatan penguasaan tanah oleh pemohon Hak Pengelolaan. Penguasaan tanah oleh pemohon ditunjukkan dengan:

1. Bukti pemilikan dan bukti perolehan tanah berupa sertpikat, penunjukan ataupenyerahan dari pemerintah, pelepasan kawasan hutan dari instansi yang berwenang, akta pelepasan bekas tanah milik adat atau bukti perolehan tanahlainnya;

2. Letak, batas-batas dan luasnya (jika ada Surat Ukur atau Gambar Situasi, 
sebutkan tanggal dan nomornya);

3. Status tanahnya (tanah hak atau tanah negara);

4. Keterangan mengenai jumlah bidang, luas dan status tanah- tanah yang dimilikioleh pemohon, ternasuk bidang tanah yang dimohon;

Bukti-bukti terkait yang harus disiapkan yaitu:

1. Bukti pemilikan dan bukti perolehan tanah berupa sertipikat, penunjukan atau penyerahan dari pemerintah, pelepasan kawasan hutan dari instansi yang berwenang, akta pelepasan bekas tanah milik adat atau bukti perolehan tanah lainnya; Surat persetujuan atau rekomendasi dari instansi terkait apabila diperlukan;

2. Surat ukur apabila ada.

3. Surat pernyataan atau bukti bahwa seluruh modalnya dimiliki oleh pemerintah.

Pemerintah harus memiliki 3 (tiga) aspek persyaratan sebagai dasar bukti penguasaan terhadap tanah aset tersebut, yaitu:

1. Bukti terang benderang;

2. Bukti dikuasai secara nyata; dan

3. Tidak ada masalah.

Bukti terang benderang dapat diartikan sebagai Barang milik Negara/Daerah tersebut memang benar-benar ada. Jenisnya dapat diketahui secara pasti yaitu tergolong sebagai tanah negara atau tanah adat. Harus memiliki bukti dokumen asli atau alat bukti hak lama sebagaimana dimaksud Pasal 24 ayat (1) Peraturan Pemerintah Nomor 24 Tahun 1997 jo. Pasal 60, dan 76 Peraturan Menteri Negara Agraria/Kepala BPN Nomor 3 tahun 1997. Namun, apabila tidak lengkap, dapat dilengkapi dengan bukti lain, misalnya bukti pembayaran PBB 
atau kwitansi pembelian tanah, dan disertai dengan pernyataan yang bersangkutan, dan keterangan dari sekurang-kurangnya 2 (dua) orang saksi, yang tidak mempunyai hubungan keluarga dengan yang bersangkutan, yang menyatakan adalah benar pemilik bidang tanah tersebut.

Jika bukti kepemilikan tersebut tidak ada, maka permohonan harus menyertakan:

1. surat pernyataan dari pemohon yang menyatakan hal-hal sebagai berikut:

a. Bahwa pemohon telah menguasai secara nyata tanah yang bersangkutan selama 20 tahun atau lebih secara berturut- berturut, atau telah memperoleh penguasaan itu dari pihak atau pihak-pihak lain yang telah menguasainya, sehingga waktu penguasaan, pemohon dan pendahulunya tersebut berjumlah 20 tahun atau lebih;

b. bahwa penguasaan tanah itu telah dilakukan dengan iktikad baik;

c. bahwa penguasaan itu tidak pernah diganggu gugat, dan karena itu dianggap diakui dan dibenarkan oleh masyarakat hukum adat atau desa/kelurahan yang bersangkutan;

d. Bahwa secara fisik tanahnya secara nyata dikuasai dan digunakan sendiri oleh pihak yang bersangkutan;

e. bahwa tanah tersebut sekarang tidak dalam sengketa;

f. Bahwa apabila pernyataan tersebut memuat hal-hal yang tidak sesuai dengan kenyataan, penandatangan bersedia dituntut dimuka Hakim secara pidana maupun perdata, karena memberikan keterangan palsu.\

2. Keterangan dari Kepala Desa/Lurah dan sekurangnya-kurangnya 2 (dua) orang saksi yang kesaksiannya dapat dipercaya, karena fungsinya sebagai tetua adat setempat dan/atau penduduk yang sudah lama bertempat tinggal di desa/kelurahan letak tanah yang bersangkutan, dan tidak mempunyai 
hubungan keluarga pemohon sampai derajat kedua, baik dalam kekerabatan vertikal maupun horizontal, yang membenarkan apa yang dinyatakan oleh pemohon dalam surat pernyataan diatas, Bukti dikuasai secara nyata yaitu tanah tersebut diberi pagar, dirawat secara periodik, dan dipergunakan sebagaimana peruntukannya. Selain hal itu, Barang milik Negara/Daerah tersebut harus memiliki batas-batas tanah yang jelas, tidak ada konflik batas ataupun konflik lainnya.

\section{Titik Product ( Sertifikasi Tanah )}

Sertifikasi tanahmerupakan titik terakhir yaitu titik product. Pasal 12 ayat (2) Peraturan Menteri Agraria dan Tata Ruang/Kepala Badan Pertanahan Nasional Nomor 17 Tahun 2016 tentang Penataan Pertanahan di Wilayah Pesisir dan Pulau- Pulau Kecil menegaskan bahwa Penggunaan dan pemanfaatan tanah dicatat dalam buku tanah dan sertipikat. Oleh karena itu Pendaftaran Hak Pengelolaan wajib dilaksanakan oleh instansi yang membutuhkan. Permohonan pendaftaran Hak Pengelolaan ditindak lanjuti oleh Kantor Pertanahan dengan tahapan sebagai berikut:

1. Pemohon mengajukan permohonan Hak Pengelolaan kepada Menteri melalui Kepala Kantor wilayah Pertanahan yang daerah kerjanya meliputiletak tanah yang bersangkutan disertai berkas- berkas sebagaimana disebutkan dalam sub bab perizinan tanah dan penguasaan tanah di atas.

2. Setelah berkas permohonan diterima, Kepala Kantor Pertanahan melakukan tindakan: ${ }^{3}$

a memeriksa dan meneliti kelengkapan data yuridis dan data fisik.

b. mencatat pada formulir isian.

c. memberikan tanda terima berkas permohonan.

d. memberitahukan kepada pemohon untuk membayar biaya- biaya yang

\footnotetext{
${ }^{3}$ Perpres nomor 71 tahun 2012
} 
diperlukan untukmenyelesaikan permohonan tersebut dengan rinciannya sesuai ketentuan peraturan perundang-undangan yang berlaku.

3. Kepala Kantor Pertanahan memeriksa kelayakan permohonan tersebut untuk diproses lebih lanjut sesuai denganketentuan peraturan perundangundangan yang berlaku.

4. Dalam hal tanah yang dimohon belum ada surat ukurnya. Kepala Kantor Pertanahan memerintahkan kepada Kepala Seksi Infrastruktur Pertanahan untuk mempersiapkan surat ukur atau melakukan pengukuran.

5. Selanjutnya Kepala Kantor Pertanahan memerintahkan kepada ;

a. Kepala Seksi Pengadaan Tanah atau petugas yang ditunjuk untuk memeriksa permohonan hak terhadap tanah yang sudah terdaftar, sepanjang data yuridis dan data fisiknya telah cukup untuk mengambil keputusan yang dituangkan dalam Risalah Pemeriksaan Tanah (konstatering Rapport); atau

b. Tim Penelitian Tanah untuk memeriksa permohonan hak terhadap tanah yang belum terdaftar yang dituangkan dalam berita acara; atau

c. Panitia Pemeriksa Tanah A untuk memeriksa permohonan hak terhadap tanah selainyang diperiksa sebagaimana dimaksud pada huruf a dan hurufb, yang dituangkan dalam Risalah Pemeriksaan Tanah.

6. Dalam hal data yuridis dan data fisik belum lengkap Kepala Kantor Pertanahanmemberitahukan kepada pemohon untuk melengkapinya.

7. Setelah permohonan telah memenuhi syarat. Kepala Kantor Pertanahan yang bersangkutan menyampaikan berkas permohonan tersebut kepada Kepala Kantor Wilayah disertai pendapat dan pertimbangannya.

8. Setelah menerima berkas permohonan yang disertai pendapat dan pertimbangan, Kepala Kantor Wilayah memerintahkan kepada Kepala Bidang Hak-hak Atas Tanah untuk:

a. Mencatat dalam formulir isian. 
b. Memeriksa dan meneliti kelengkapan data yuridis dan data fisik, dan apabila belumlengkap segera meminta Kepala Kantor Pertanahan yang bersangkutan untuk melengkapinya.

9. Kepala Kantor Wilayah memeriksa kelayakanpermohonan Hak Pengelolaan tersebut untuk diproses lebih lanjut sesuai denganketentuan peraturan perundang-undangan yang berlaku.

10. Setelah permohonan telah memenuhi syarat. Kepala Kantor Wilayah yang bersangkutanmenyampaikan berkas permohonan tersebut kepada Menteri disertai pendapat danpertimbangannya.

11. Setelah menerima berkas permohonan yang disertai pendapat dan pertimbangan, Menteri memerintahkan kepada Pejabatyang ditunjuk untuk:

a. Mencatat dalam formulir isian.

b. Memeriksa dan meneliti kelengkapan data yuridis dan data fisik, dan apabila belumlengkap segera meminta Kepala Kantor Wilayah yang bersangkutan untukmelengkapinya.

12. Menteri meneliti kelengkapan dan kebenaran data yuridis dan data fisik atas tanah yangdimohon dengan memperhatikan pendapat dan Pertimbangan Kepala Kantor Wilayah dan selanjutnya memeriksa kelayakan permohonan tersebut dapat atau tidaknya dikabulkan sesuai dengan ketentuan peraturanperundang-undangan yang berlaku.

13. Menteri menerbitkan keputusan pemberian Hak Pengelolaan atas tanah yang dimohon atau keputusan penolakan yangdisertai dengan alasan penolakannya.

14. Keputusan pemberian atau penolakan pemberian Hak Pengelolaan disampaikan kepada pemohon melalui surat tercatat atau dengan cara lain yang menjamin sesampainya keputusan tersebut kepada yang berhak.

Dari ketentuan - ketentuan tersebut di atas maka sebaiknya peraturan pemerintah daerah yang akan dibentuk harusnya memuat konsep 3 in 1 in the 
Land Acquisition, ${ }^{4}$ yang berisi tahapan - tahapan pengelolaan dan penyerhan PSU pada suatu kawasan perumahan, pemukiman, kawasan industri dan kawasan perdagangan/ jasa yang telah disebutkan sebelumnya. Karena konsep ini merupakan kegiatan awal sampai akhir atau dari hulu ke hilir baik dari titik start yang dimana izin siteplane ( izin lokasi ) merupaka proses awal tahapan yang harus di peroleh oleh pengembang. Pada prsoses ini sudah ada penetapan dari pemerintah daerah selaku instansi yang berwenang menerbitkan izin siteplane (izin lokasi) tentang prosentase pembagian 30\% 40\% untuk fasilitas umum dan $70 \%$ atau $60 \%$ untuk bangunan dari seluruh totalluasan tanah yang di daftarkan oleh pengembang. Yang mana sudah Dijelaskan bahwa dalam Pasal 7, 8, dan 9 Peraturan Menteri Dalam Negara No. 9 Tahun 2009 yang mengatur Tentang Pedoman Penyerahan Prasarana, sarana, dan Utilitas (PSU) Perumahan dan Permukiman Daerah.

karena fasum suatu kawasan perumahan adalah salah satu kebutuhan pokok perumahan, dimana perumahan merupakan kumpulan rumah sebagai bagian dari permukiman, baik perkotaan maupun pedesaan, yang harusnya dilengkapi dengan prasarana, sarana dan utilitas atau biasa disebut dengan PSU sebagai hasil upaya pemenuhan kawasan perumahan yang layak huni dan Fasilitas umum harus disediakan oleh pengembang dalam pembangunan perumahan.

\section{Apa status tanah fasum yang disalah gunakan peruntukkannya dan diperjual belikan?}

Setelah semua fasilitas terpenuhi dalam jangka 1 (satu) tahun pengembang harusnya menyerahkan ke Pemerintah Daerah setempat untuk dilanjutkan pengelolaannya. Berdasarkan analisis ditemukan sering terjadi banyaknya fasilitas umum yang disalah gunakan peruntukkanya untuk diperjual belikan bahkan ada yang dengan sengaja tidak diserahkan oleh pengembang kepada

\footnotetext{
${ }^{4}$ Strategi Ampuh Kuasai Hukum Pertanahan Dr. H. Jarot Widya Muliawan, S.H., CN., M.kn.
} 
Pemerintah Daerah setempat setelah 1 (satu) tahun atau setelah selesai pembangunan perumahan. Hal ini menunjukkan bahwa pengembang tidak memenuhi salah satu syarat dalam Pasal 12 Permendagri No. 9 Tahun 2009. Dalam hal ini pengembang masih mempunyai kewenangan dalam jangka 1 (satu) tahun untuk menggunakan fasilitas umum yang belum diserahkan kepada Pemerintah Daerah setempat. Status hak atas tanah sebelumpenyerahan yaitu Hak Guna Bangunan (HGB) dan setelah Penyerahan yang dilakukan oleh pengembang kepada Pemerintah Daerah setempat dan didaftarakan di Kantor Pertanahan, maka hak atas tanahnya berubah menjadi tanah Negara. Pengembang menyerahkan prasarana, sarana dan utilitas kepada Pemerintah Daerah setempat harusnya ada Berita Acara Serah terima Penyerahan dan Akta Pelepasan Hak. Setelah penyerahan kepada Pemerintah Daerah setempat, prasarana, sarana dan utilitas diserahkan kepada Satuan Kerja Pemerintah Daerah (SKPD) yang berwenang mengelola dan memelihara. Penyerahan prasarana, sarana dan utilitas paling lambat 3 (tiga) bulan setelah Kantor Pertanahan menerbitkan hak pakai atas tanah kepada Satuan Kerja Pemerintah Daerah (SKPD).

\section{Penutup}

\section{Kesimpulan}

Dalam penyerahan prasarana, sarana dan utilitas suatu kawasan perumahan dan pemukiman perlunya pemerintah daerah membuat suatu peraturan daerah yang berkenaan dengan penyerahan dan pengelolaan tanah fasum harusnya memuat konsep konsep 3 in 1 in the Land Acquisition, yang berisi tahapan tahapan dari kegiatan awal sampe akhir, yang akhirnya bermuara pada tiga titik tahapan, yaitu 1 (satu) titik start adalah tahapan penetapan izin lokasi pengembang dengan diserati siteplane (rencana tapak) oleh pemerintah daerah, tahapan ke 2(dua) titik decision, tahapan ini menitik beratkan pada aspek penguasaan dari pengembang kepada pemerintah daerah yang dilakukan 
dengan cara penyerahan siteplane, dan tahapan ke 3 (tiga) titik product, peneribitan sertifikasi tanah ( hak pakai) oleh BPN ( Badan Pertanahan Nasioanl) kepada pemerintah daerah sesuai dengan ketetapan Permendagri nomor 9 tahun 2009.

\section{Saran}

Meski pengaturan penyerahan PSU atau tana Fasum telah termuat dalam peraturan daerah, ternyata banyak peraturan daerah tersebut tidak mengatur tata cara penyerahan dan penglolaan fasum secara spesifik, hingga perlunya pembentukan peraturan daerah yang ada memuat konsep 3 in 1 in the Land Acquisition dengan berisi tahapan - tahapan pengelolaan dan penyerhan PSU pada suatu kawasan perumahan, pemukiman, kawasan industri dan kawasan perdagangan/ jasa yang telah disebutkan sebelumnya, karena konsep 3 in 1 in the Land Acquisition ini merupakan kegiatan awal sampai akhir atau dari hulu ke hilir baik dari titik start yang dimana izin siteplane ( izin lokasi ) merupaka proses awal tahapan yang harus di peroleh oleh pengembang, hingga nantinya hak pakai atas tanah fasum sebagai asset milik pemerintah daerah agar bisa dilakukan pengawasan untuk pemeliharaan dan pengelolaannya serta bekerjasama dengan masyarakat sekitar yang berdampak langsung akan nilai manfaat sosial serta manfaat ekonomi akan adanya fasum pada kawasan rumah tinggal maupun non rumah tinggal, sesuai dengan ketetapan Permendagri nomor 9 tahun 2009. 


\section{Daftar Pustaka}

Jarot Widya Muliawan, Strategi Ampun Kuasai Hukm Pertanahan “Konsep 3 In 1

The Land Acquisition sebagai konsep penyelesaian Masalah Tanah Fasum / PSU.

http://bisnisproperty.net/dokumen-properti-yang-terkait-tata-ruang,diakses hari Sabtutanggal 20 Desember 2020 : 22.24 WIB.

Undang - undang Dasar Negara Republik Indonesia Tahun 1945

Peraturan menteri agrarian dan tata ruang/ kepala Badan pertanahan nomor 5 tahun2015

Peraturan Menteri Dalam Negeri nomor 9 tahun 2009 tentang penyerahan Prasarana,Sarana dan Utilitas Perumahan dan permukiman di Daerah. 